\title{
Plant Pathology
}

An international journal edited by the British Society for Plant Pathology

Senior Editor

P.R. Scott

$C A B$ International, Wallingford, Oxon, $U K$
Deputy Editor

M.J.C. Asher

Bury St. Edmunds, UK

\section{Editorial Board}

K.W. Bailiss Wye

J.R. Coley-Smith Hull

I.R. Crute Wellesbourne

C.M.E. Garrett East Malling

M. Gratwick Harpenden

S.A. Hill Harpenden
D.S. Ingram Cambridge

M.J. Jeger London

G.J. Jellis Cambridge

D.H. Lapwood Harpenden

K.J. Leonard N. Carolina

E. Lester Harpenden
B.G. Lewis Norwich

C. Logan Belfast

J.P. Ride Birmingham

D.J. Royle Bristol

R.C. Shattock Bangor.

P.W. Talboys East Malling

Plant Pathology publishes research papers and critical reviews on all aspects of the subject, including such topics as:

- Diseases of temperate and tropical plants caused by fungi, viruses, virus-like organisms and bacteria

- Methods in plant pathology

- Physiological, biochemical, ecological, genetic and economic aspects of plant pathology

- Disease appraisal and crop loss assessment

- Plant disease control, including disease-related crop management

Short reports of new or unusual records of plant diseases are welcomed, as are letters to the editor when these comment on matters relevant to plant pathology.

\section{Subscription Information}

Plant Pathology is published quarterly. Subscription rates for 1988 are $£ 82.00$ (UK), US\$167.50 (USA \& Canada), $£ 98.50$ (elsewhere) post free.

\section{Order Form}

Please tick the appropriate box and return to Blackwell Scientific Publications Ltd, P.O. Box 88, Oxford, England.

$\square$ I would like to subscribe to Plant Pathology

I wish to pay by cheque/money order (delete as necessary) and enclose the sum of

I wish to pay by Access/Barclaycard/VISA/Mastercard (delete as necessary)

Please debit my credit card no.

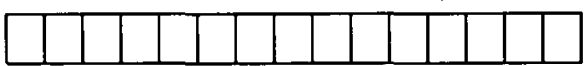

Expiry date. with the sum of

Signature

Date

Please send me a specimen copy of Plant Pathology

Name

Address.

\section{Blackwell Sclentific Publications}

P.O. Box 88, Oxford, England 


\section{The Journal of \\ Agricultural Science}

EXECUTIVE EDITOR

Miss Jane King

Department of Applied Biology, Pembroke Street, Cambridge CB2 3DX, UK

EDITED BY

E. J. Allen

University of Cambridge, $U K$

R. B. Austin

Institute of Plant Science Research

(Cambridge Laboratory), UK

B. W. Bache

University of Cambridge, $U K$

Sir James Beament

University of Cambridge, UK

G. D. H. Bell

Cambridge, UK

Sir Kenneth Blaxter

Stradbroke, UK

A. D. Care

University of Leeds, UK

J. A. Currie

Harpenden, UK

W. Day

ARFC Engineering, Silsoe, UK
S. K. Eltringham

University of Cambridge, UK

W. G. Hill

University of Edinburgh, $U K$

G. Jenkins

Plant Breeding International

(Cambridge), UK

A. E. Johnston

Institute of Arable Crops Research, Rothamsted, UK

R. N. B. Kay

Aberdeen, UK

C. N. Law

Institute of Plant Science Research (Cambridge Laboratory), UK

D. B. Lindsay

Tropical Cattle Research Centre, Australia

G. M. O. Maloiy

University of Nairobi, Kenya
J. B. Owen

University College of North Wales, UK

M. Peaker

Hannah Research Institule, UK

P. E. Russell

Chesterford Park Research Station, $U K$

S. K. Sinha

Indian Agricultural Research Institute, India

D. E. Walters

Institute of Animal Physiology and Genetics Research (Cambridge), UK

D. Wilman

University College of Wales, Aberystwyth, UK

F. Yates

Rothamsted Experimental Station, UK

VOLUME 111

CAMBRIDGE UNIVERSITY PRESS

Cambridge

New York Rochelle Melbourne Sydney

1988 


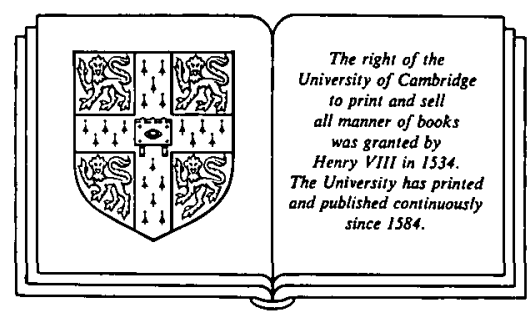

PUBLISHED BY

THE PRESS SYNDICATE OF THE UNIVERSITY OF CAMBRIDGE

The Pitt Building, Trumpington Street, Cambridge CB2 1RP

32 East 57th Street, New York, NY 10022, USA

10 Stamford Road, Oakleigh, Melbourne 3166, Australia

(C) Cambridge University Press 1988 


\section{CONTENTS}

\section{PART 1 (AUGUST 1988)}

Instructions to Authors

PAGE

MCCABE, SHARON M. AND BARRY, T. N. Nutritive value of willow (Salix sp.) for sheep, goats and deer

RUDOLF, I. G. W., BLAIR, G., ORCHARD, P. W., TILL, A. R. AND HUNT, M. The performance of Ongole heifers grazing native and introduced pasture species at Sumba, Indonesia

KRYSL, L. J., GALYEAN, M. L., ESTELL, R. E. AND SOWELL, B. F. Estimating digestibility and faecal output in lambs using internal and external markers

el-Nouty, F. D., hassan, G. A., TAher, T. H., SamaK, M. A., abo-elezz, ZahraA and Salem, M. H. Water requirements and metabolism in Egyptian Barki and Rahmani sheep and Baladi goats during spring, summer and winter seasons

MORRISON, I. M. Influence of some chemical and biological additives on the fibre fraction of lucerne on ensilage in laboratory silos

NOUR, A. Y. M. AND THONNEY, M. L. Minerals of carcass soft tissue and bone of serially slaughtered cattle as affected by biological type and management

SADANA, U. S. AND TAKKAR, P. N. Effect of sodicity and zinc on soil solution chemistry of manganese under submerged conditions

DE, MAINE, M. J., BAIN, H. AND JOYCE, JACQUeline A. L. Changes in total tuber glycoalkaloid content of potato cultivars on exposure to light

ChIfamba, IRENe K., WARD, H. K., TA WONeZVi, H. P. R., SMith, C. AND Khombe, C. T. Productivity of Zimbabwean indigenous sheep, German Mutton Merino and their crosses on range

SAINZ, MARIA J. AND ARINES, J. Effects of native vesicular-arbuscular mycorrhizal fungi and phosphate fertilizer on red clover growth in acid soils

BRIGNALL, D. M., WARD, M. R. AND WhitTINGTON, W. J. Yield and quality of triticale cultivars at progressive stages of maturity

FIRMAN, D. M. AND ALLEN, E. J. Field measurements of the photosynthetic rate of potatoes grown with different amounts of nitrogen fertilizer

ChAKRABORTY, P. K., MANDAL, L. N. AND MAJUMDAR, aNUP. Organic and chemical sources of nitrogen: its effect on nitrogen transformation and rice productivity under submerged conditions

TSER VENI-GOUSI, A. S. AND YANNAKOPOULOS, A. L. Specific gravity, carcass fat and prediction of fatness in quail carcasses

ABDelraZiK, M. A., El-SAYIAD, GH. A., MARAi, I. F. M. AND Soliman, M. M. Effect of different combinations of light and dark regimes on the performance of egg lay events, fertility and plasma steroid hormones, during the ovulatory cycle in Peking ducks

HOWE, J. C., BARR Y, T. N. AND POPAY, A. I. Voluntary intake and digestion of gorse (Ulex europaeus) by goats and sheep

VERMA, R. S. AND YADA V, R. L. Nitrogen response of autumn planted sugar cane grown with various companion crops

JENA, P. K. AND RAJARAMAMOHAN RAO, v. Influence of salinity, rice straw and water regime on nitrogen fixation in paddy soils

SPOelstra, S. F., COURTIN, M. G. and VAN BeERS, J. A. C. Acetic acid bacteria can initiate aerobic deterioration of whole crop maize silage

PATERSON, L. J., WILD, P. and WilliamS, E. R. An algorithm to generate designs for variety trials

SYMONDS, M. E., BRYANT, M. J. and LOMAX, M. A. Metabolic adaptation during pregnancy in wintershorn sheep

BRoSh, A., CHOSHNIAK, I., TADMOR, A. and SHKolNik, A. Physico-chemical conditions in the rumen of Bedouin goats - effect of drinking, food quality and feeding time

HUNDAL, H. S. A mechanism of phosphate adsorption on Narrabri medium clay loam soil 
SIYAG, R. S., LAMBA, M. S., PAL, RAJ and POONIA, S. R. Predicting sodification of calcium-saturated soil columns on leaching with sodic waters

QUIRK, M. F., BUSHELL, J. J., JONES, R. J., MEGARRITY, R. G. and BUTLER, K. L. Live-weight gains on leucaena and native grass pastures after dosing cattle with rumen bacteria capable of degrading DHP, a ruminal metabolite from leucaena

STOUT, D. G., HALL, J., BROOKE, BARBARA and MOORE, T. A field method for evaluating frost injury to lucerne

PhIPPS, R. H., WELleR, R. F., ElliotT, R. J. and sutton, J.D. The effect of level and type of concentrate and type of conserved forage on dry matter intake and milk production of lactating dairy cows

SHORT NOTES

HUNTER, R. A. and VERCOE, J. E. Effect of oestradiol-17 $\beta$ on energy metabolism of steers fed roughage diets

SAHOTA, T. S., VIRK, M. S. and GOVINDAKRISHNAN, P. M. Spot $v$. furrow placement of phosphorus in potato at Shillong

SHARMA, R. C. and SHARMA, H. C. Usefulness of organic manures and their nitrogen fertilizer equivalents

SA JWAN, K. S. and LINDSAY, W. L. Response of flooded rice to various sources of zinc

ELKASED, F. A., LOMBIN, G. and NNADI, L. A. Response of tobacco (Nicotiana tabacum) to Mg and K application on some alfisols and inceptisols of northern Nigeria

BOOK REVIEWS

\section{PART 2 (OCTOBER 1988)}

Instructions to Authors

MAGAT, S. S. AND GOH, K. M. Effects of chloride fertilizers on yield and uptake of chloride, potassium and sodium by fodder beet (Beta vulgaris L.) in two New Zealand soils

OGUNTONA, TUNDE. Effects of dietary levels of oxytetracycline on the growth and organ weights of guinea fowl (Numida meleagris)

HUSAIN, M. M., HILL, G. D. AND GALlaGHER, J. N. The response of field beans (Vicia faba L.) to irrigation and sowing date 1 . Yield and yield components

HUSAin, M. M., HILL, G. D. AND GALlaGHER, J. N. The response of field beans (Vicia faba L.) to irrigation and sowing date 2 . Growth and development in relation to yield

MÜSCHEN, H., PETRI, A., BREVES, G. AND PFEFFER, E. Response of lactating goats to low phosphorus intake 1. Milk yield and faecal extraction of $P$ and $C a$

PETRI, A., MÜSCHEN, H., BREVES, G., RICHTER, O. AND PFEFFER, E. Response of lactating goats to low phosphorus intake 2. Nitrogen transfer from rumen ammonia to rumen microbes and proportion of milk protein derived from microbial amino acids

BROCK, J. L., HAY, M. J. M., THOMAS, v. J. AND SEDCOLE, J. R. Morphology of white clover (Trifolium repens $\mathrm{L}$.) plants in pastures under intensive sheep grazing

THORNE, G. N. AND WOOD, D. W. Contributions of shoot categories to growth and yield of winter wheat

ABDEL MONEIM, A. M., COCKS, P. S. AND SWEDAN, Y. Yield stability of selected forage vetches (Vicia spp.) under rainfed conditions in west Asia

DEGEN, A. A., KAM, M. AND ROSENSTRAUCH, A. Efficiency of utilization of energy for egg production in feed-restricted single comb White Leghorn hens

NAKAI, H., Katsumata, K., GOHDA, M., WATANABE, J. AND KOIKE, K. Modification of host-parasite interactions through mutagenesis in quantitative resistance of rice to bacterial leaf blight

DYKE, G. V. Changes with time of crop yields in a long-term experiment

FADAYOMI, $o$. Weed control in sugar cane with hexazinone alone and in combination with diuron

LILL, W. J., GLEESON, A. C. AND CULLIS, B. R. Relative accuracy of a neighbour method for field trials 
KEILLER, D. R. AND MORGAN, D. G. Distribution of ${ }^{14}$ carbon-labelled assimilates in flowering plants of oilseed rape (Brassica napus L.)

KEILLER, D. R. AND MORGAN, D. G. Effect of pod removal and plant growth regulators on the growth, development and carbon assimilate distribution in oilseed rape (Brassica napus L.)

RUVUNA, F., CARTWRIGHT, T. C., BLACKBURN, H., OKEYO, M. AND CHEMA, S. Gestation length, birth weight and growth rates of pure-bred indigenous goats and their crosses in Kenya

SMALL, J. C. AND GORDON, F. J. The effect of system of harvesting grass for silage on the output of silage and milk per hectare

HIPPS, N. A. AND HODGSON, D. R. Residual effects of a slant-legged subsoiler on shoot growth and grain yield of spring barley

SHORT NOTES

ODOEMENA, C. s. Breaking of seed coat dormancy in a medicinal plant Tetrapleura tetraptera (Schum \& Thonn)

SIDHU, B. S., BERI, V. and MEELU, O. P. The effect of soil temperature modification on the natural pigeonpea (Cajanus cajan L.)-Rhizobium symbiosis

CHUNG, B., ARMSTRONG, D. and GRICE, SUE Effect of irrigation frequency on the incidence of second growth of Russet Burbank potatoes in north-west Tasmania

O'KELLY, J. C. and SPIERS, W. G. Monensin induced metabolic changes in cattle fed a restricted intake of lucerne hay

ONI, O. O., BuVANENDRAN, v. and DIM, N. I. Factors affecting birth weight and performance to weaning of Bunaji calves

BOOK REVIEWS

PART 3 (DECEMBER 1988)

\section{Editorial}

Instructions to Authors

GOSWAMI, N. N., PRASAD, R., SARKAR, M. C. AND SINGH, S. Studies on the effect of green manuring in nitrogen economy in a rice-wheat rotation using a ${ }^{15} \mathrm{~N}$ technique

ROBINSON, DOROTHY L., KERSHA W, C. D. ANDELLIS, R. P. An investigation of two-dimensional yield variability in breeders' small plot barley trials

WURR, D. C. E., ELPHINSTONE, E. D. AND FELLOWS, JANER. The effect of plant raising and cultural factors on the curd initiation and maturity characteristics of summer/autumn cauliflower crops

BLAIR, G. J., PAN JAITA N, MAS'UD, IVORY, D. A., PALMER, B. AND SUDJADI, M. An evaluation of tree legumes on an acid ultisol in South Sumatra, Indonesia

FERGUSON, C. M., BaRRATt, B. I. P. AND JONES, P. A. Control of the grey field slug (Deroceras reticulatum (Muller)) by stock management prior to direct-drilled pasture establishment

SINGH, A. L., SINGH, P. K. AND SINGH, P. L. Effects of different herbicides on the Azolla and blue-green algal biofertilization of rice

SINGH, K. N., SHARMA, D. K. AND CHILLAR, R. K. Growth, yield and chemical composition of different oilseed crops as influenced by sodicity

SINGH, K. N., SHARMA, D. K. AND CHILLAR, R. K. Forage yield and chemical composition of pearlmillet (Pennisetum typhoides) as influenced by exchangeable sodium

MACKINNON, B. W., EASTON, H. S., BARRY, T. N. AND SEDCOLE, J. R. The effect of reduced leaf shear strength on the nutritive value of perennial ryegrass

BURNS, B. M., VERCOE, J.E. AND hOLMES, C. R. Productive and adaptive trait differences of Simmental, Hereford and Africander $\times$ Hereford cattle

WURR, D. C. E., FELLOWS, JANER. AND SUCKLING, R. F. Crop continuity and prediction of maturity in the crisp lettuce variety Saladin

NEG I, S. S., SINGH, B. AND MAKK AR, H. P. S. An approach to the determination of rumen degradability of nitrogen in low-grade roughages and partition of nitrogen therein 
SHARMA, A. R. AND MitTRA, B. N. Effect of combination of organic materials and nitrogen fertilizer on growth, yield and nitrogen uptake of rice

Doyle, P. T., Dove, H., Freer, M., hart, F. J., Dixon, R. M. AND Egan, A. R. Effects of a concentrate supplement on the intake and digestion of a low-quality forage by lambs

NNADI, L. A. AND HAQUE, I. Root nitrogen transformation and mineral composition in selected forage legumes

EL-BELELY, M. S., ZAK I, K. AND GRUNeRT, E. Plasma profiles of progesterone and total oestrogens in buffaloes (Bubalus bubalis) around parturition

SHORT NOTES

SIDHU, M. S., SAWhNeY, J. S. AND balJinder. Production potential of kharif pulses in association with maize

Rahma TUllah, Salim, M. AND SUltana, S. A. Distribution and availability of copper fractions of wheat from some loess derived alkaline calcareous soils

BOOK REVIEWS

533

CORRIGENDUM 
Copying. No contents may be reproduced by any means without the permission of Cambridge University Press. This journal is registered with the Copyright Clearance Center, 27 Congress Street, Salem, MA 01970. Organizations in the USA who are also registered with the C.C.C. may therefore copy material (beyond the limits permitted by sections 107 and 108 of US copyright law) subject to payment to C.C.C. of the per-copy fee of $\$ 5.00$. This consent does not extend to multiple copying for promotional or commercial purposes. Code 0021-8596/88 $\$ 5.00+0.00$.

ISI Tear Sheet Service, 3501 Market Street, Philadelphia, PA 19106, USA, is authorized to supply single copies of separate articles for private use only.

For all other use, permission should be sought from Cambridge or the American Branch of Cambridge University Press.

\section{CAMBRIDGE UNIVERSITY PRESS}

The Pitt Building, Trumpington Street, Cambridge CB2 1RP

32 East 57th Street, New York, NY 10022, USA

10 Stamford Road, Oakleigh, Melbourne 3166, Australia

Printed in Great Britain by the University Press, Cambridge 


\section{The Journal of Agricultural Science}

\section{CONTENTS}

Editorial Policy

Instructions to Authors

GOSWA MI, N. N., PRASA D, R., SARKAR, M. C. and SINGH, S. Studies on the effect of green manuring in nitrogen economy in a rice-wheat rotation using a ${ }^{15} \mathrm{~N}$ technique

ROBINSON, DOROTHY L., KERSHAW, C. D. and ELLIS, R. P. An investigation of twodimensional yield variability in breeders' small plot barley trials

WURR, D. C. E., ELPHINSTONE, E. D. and FELLOWS, JANER. The effect of plant raising and cultural factors on the curd initiation and maturity characteristics of summer/ autumn cauliflower crops

blair, G. J., Panjaitan, mas'ud, ivory, D. A., Palmer, b. and sudjadi, an. An evaluation of tree legumes on an acid ultisol in South Sumatra, Indonesia

FERGUSON, C. M., BarRatT, B. I. P. and jones, P. A. Control of the grey field slug (Deroceras reticulatum (Muller)) by stock management prior to direct-drilled pasture establishment

SINGH, A. L., SINGH, P. L. Effects of different herbicides on the Azolla and blue-green algal biofertilization of rice

Singh, K. N., ShaRma, D. K. and Chillar, R. K. Growth, yield and chemical composition of different oilseed crops as influenced by sodicity

SiNGH, K. N., ShARMA, D. K. and ChILlaR, R. K. Forage yield and chemical composition of pearl-millet (Pennisetum typhoides) as influenced by exchangeable sodium

MACKINNON, B. W., EASTON, H. S., BARRY, T. N. and SEDCOLE, J. R. The effect of reduced leaf shear strength on the nutritive value of perennial ryegrass

BURNS, B. M., VERCOE, J. E. and HOLMES, C. R. Productive and adaptive trait differences of Simmental, Hereford and Africander $\times$ Hereford cattle

WURR, D. C. E., FELLOWS, JANER. and SUCKLING, R. F. Crop continuity and prediction of maturity in the crisp lettuce variety Saladin

NEGI, S. S., SINGH, B. and MAKKAR, H. P. S. An approach to the determination of rumen degradability of nitrogen in low-grade roughages and partition of nitrogen therein

SHARMA, A. R. and MITTRA, B. N. Effect of combinations of organic materials and nitrogen fertilizer on growth, yield and nitrogen uptake of rice

DOYLE, P. T., DOVE, H., FREER, M., HART, F. J., DIXON, R. M. and EGAN, A. R. Effects of a concentrate supplement on the intake and digestion of a low-quality forage by lambs

NNADI, L. A. and HAQUE, I. Root nitrogen transformation and mineral composition in selected forage legumes

EL-BELELY, M. S., ZAKI, K. and GRUNERT, E. Plasma profiles of progesterone and total oestrogens in buffaloes (Bubalus bubalis) around parturition

SHORT NOTES

Sidhu, M. S., SAWhNey, J. S. and BaLJinder Production potential of kharif pulses in association with maize

RAHMATUllah, SALIM, M. and SUltana, S. A. Distribution and availability of copper fractions to wheat from some loess derived alkaline calcareous soils 